\title{
Contents of the National Interest of Indonesia in the Bilateral Investment Treaty
}

\author{
Mira Nila Kusuma Dewi ${ }^{1} \quad$ Juajir Sumardi $^{2} \quad$ Abrar Saleng $^{2} \quad$ Andi Suriyaman M. Pide ${ }^{2}$ \\ 1. Doctoral Student, Faculty of Law, Hasanuddin University, Indonesia \\ 2. Professor of Law, Faculty of Law, Hasanuddin University, Indonesia
}

\begin{abstract}
Economic cooperation between subjects of international law is generally expressed in various forms of agreements or international trade and investment between countries aimed at obtaining benefits from the parties entering into international cooperation. However, the BIT made by the Government of Indonesia still does not contain a balance between the rights and obligations of Investors and the Indonesian National Interest. This research is a normative research with statutory and case approach. The results of the study indicate that the current Indonesian investment agreement does not fully contain the national interest because it is based on social welfare based on Law No. 11 of 2009 has not been achieved by looking at the fact that there are still many people around the Freeport mining area who are still under poverty and housing and health conditions are very minimal compared to luxury buildings around the mine. In addition, the customary tribes around the investment (mining) location have their ulayat rights taken away and do not get protection. Based on economic theory, especially the middle way theory, investment agreements should not only provide benefits to investors but must also provide benefits to the recipient country of capital in this case the national interest.
\end{abstract}

Keywords: Bilateral Investment Treaty, National Interest, Indonesia

DOI: $10.7176 / J L P G / 115-04$

Publication date: November $30^{\text {th }} 2021$

\section{A. Introduction}

The era of world globalization has affected every country in various fields, whether political, legal, economic, social and cultural as well as defense and security along with the increasing flow of information through various media, both internet, television, and newspapers. Economic globalization is one of the many currents of globalization that are emitting waves, which have made the interdependence of the world economy even stronger. ${ }^{1}$ International economic relations between subjects of international law in the era of globalization have led to increased cooperation between subjects of international law. Economic cooperation between subjects of international law is generally poured into various forms of agreements ${ }^{2}$ which are expected to provide benefits for subjects of international law who cooperate so that it is expected to increase economic growth in each country of origin of subjects of international law who cooperate. ${ }^{3}$

Cooperation between subjects of international law in the economic field, both in the form of international trade and investment between countries, aims to benefit from the parties entering into international cooperation ${ }^{4}$, in its development leading to an international economic law system.

Investment is a form of cooperation between subjects of international law in the economic field. Investment or investment is one of the tools to drive the economic growth of a country. Investment can be in the form of foreign investment or domestic investment. Foreign investment is the flow of assets from one country to another with the aim of making a profit, with the supervision of the owner of the fund. The flow of assets can be in the form of physical property which is a Foreign Direct Investment hereinafter referred to as FDI, or the flow of assets to buy company shares in other countries which is a form of portfolio investment or indirect investment (portfolio investment). ${ }^{5}$ Investment is a form of cooperation between subjects of international law in the

\footnotetext{
${ }^{1}$ Sumardi, J. (2012). Hukum perusahaan transnasional \& franchise. Makassar: Arus Timur. p. 4

${ }^{2}$ Based on the Vienna Convention on the Law of Treaties, which was established on 23 May 1969 and entered into force on 27 January 1980 , in article 2, a treaty can be defined as an agreement in which two or more countries enter into or intend to enter into relations between them. and regulated in international law... View Official Site United Nation, Depository, Status of Treaties, https://treaties.un.org/pages/ViewDetailsIII.aspx?src=TREATY\&mtdsg_no=XXIII-1\&chapter=23\&Temp=mtdsg3\&clang=_en $($ accessed on 31 March 2021).

${ }^{3}$ Bjorklund, A. (2005). Foreword: Symposium: Romancing the Foreign Investor Bit by Bit. UC Davis Journal of International Law and Policy, 12(1).p. 1

${ }^{4}$ From his discovery of Comparative Advantage, Ricardo draws the following conclusions, as follows: "In a free trade system, each country naturally allocates its capital and labor to the jobs that are most profitable for it. This pursuit of individual profit is closely linked to the universal good of all by giving impetus to industry, rewarding ingenuity, and by making the most efficient use of the special powers that nature bestows, it distributes labor most effectively and most economically, meanwhile, by increasing mass production in general, it spreads profit in general, and binds with one common interest, the society of nations throughout the civilized world. Ricardo, D. (1891). Principles of political economy and taxation. G. Bell and sons. p.51. See also, Hata, (2021). Perdagangan internasional dalam sistem GATT dan WTO; Aspek-aspek hukum dan non hukum. Bandung: Refika Aditama. p. 17.

${ }^{5}$ M Sornarajah, M. (2021). The international law on foreign investment. New York: Cambridge university press. p. 8
} 
economic field. Investment or investment is one of the tools to drive the economic growth of a country. Investment can be in the form of foreign investment or domestic investment. Foreign investment is the flow of assets from one country to another with the aim of making a profit, with the supervision of the owner of the fund. The flow of assets can be in the form of physical property which is a foreign direct investment hereinafter referred to as FDI, or the flow of assets to buy company shares in other countries which is a form of portfolio investment or indirect investment (portfolio investment). Foreign investment can be considered as an engine of economic growth, a source of foreign exchange earnings, a driver of the local economy, and a source of foreign skills, information and knowledge. ${ }^{1}$

World Trade Organization/WTO ${ }^{2}$ states that FDI has become the main driver of the globalization process. $^{3}$ FDI is still considered as capital that has a significant impact, including technology transfer and managerial know-how. ${ }^{4}$ In general, the subjects of international law make an international treaty or agreement to cooperate in the investment sector, which is then called International Investment Agreements/IIAs. One type of PII is the Bilateral Investment Treaty or hereinafter referred to as the Bilateral Investment Treaty (BIT). ${ }^{5}$

Since the end of World War II more than 3000 IIAs have been signed by the countries of the world. ${ }^{6}$ Although these investment agreements are legally separate and distinct, they have the same structure, objectives and principles. This has established the so-called investment treaty regime. ${ }^{7}$ The legal consequences of this investment treaty regime are very important to determine the impact on contractual relationships, especially on three important aspects in the internationalization of investment contracts. The three aspects are: (a) Direct granting of rights to foreign investors; (b) the consequences of the breach of the agreement; (c) application of international law. ${ }^{8}$

BIT, also known as Investment Promotion and Protection Agreement, is basically an investment agreement signed by two countries and binds the rights and obligations in facilitating the entry of investment in each country, which generally contains two things, namely promotion and protection. ${ }^{9}$

BIT as an agreement containing terms of promotion can be interpreted that BIT is used by countries with the aim of promoting the transfer of capital, technology and managerial capabilities, improving the economy, economic efficiency, competition and increasing market access and avoiding the threat of expropriation of assets without compensation ${ }^{10}$, which is one of the risks of investment resulting from regime change or changes in the political and economic policies of the host state. ${ }^{11}$

BIT is an investment agreement that contains protection with the intention that BIT provides protection for foreign investors' capital in a country's territory by providing clear rules regarding the host state's treatment of investments and establishing dispute resolution mechanisms that can be applied if there are allegations of violation of these rules. $^{12}$

BIT regulates investment protection standards that must be carried out by the host state, such as ${ }^{13}$ :

1) Equal and fair treatment or no discrimination from all types of investment, both foreign and domestic;

2) Full protection and security which includes the state's obligation to provide compensation for

\footnotetext{
${ }^{1}$ QC, S. P. S. (2020). International investment law: reconciling policy and principle. New York: Bloomsbury Publishing. p. 83.

${ }^{2}$ Definition WTO: "The overall objective of the WTO is to help its members use trade as a means to raise living standards, create jobs and improve people's lives. The WTO operates the global system of trade rules and helps developing countries build their trade capacity. It also provides a forum for its members to negotiate trade agreements and to resolve the trade problems they face with each other." Accessed on https:/www.wto.org/english/thewto e/whatis e/who we are e.htm.

${ }^{3}$ Renato Ruggiero, "WTO News, 1996 Press Release", $\bar{h}$ ttp://www.wto.org/english/news_e/pres96_e/pr042_e.html. (Accessed on 25 October 2019).

${ }^{4}$ Arie Afriansyah, Trends in the Preparation of International Investment Agreements, was presented at the Webinar "Indonesia and the Future of International Investment Agreements" on Tuesday, November 3, 2020 via Zoom, in commemoration of the 69th Anniversary of the Faculty of Law, University of Indonesia.

${ }^{5}$ International Investment Agreements are devided into two types: (1) Bilateral Investment Treaties (BITs), (2) Treaties with Investment Provision (TIPs). Terminology of International Investment Agreements Navigator, https://investmentpolicy.unctad.org/internationalinvestment-agreements\#: :text=A\%20bilateral\%20investment $\% 20$ treaty $\% 20$ (BIT,countries $\% 20$ in $\% 20$ each $\% 20$ other's\%20territory. (Accessed on 15 March 2020).

${ }^{6}$ There are 3 types of investment agreements, namely 1) Bilateral Investment Treaties (BITs) as many as 2608 agreements effective at the end of 2008, 2) approximately 254 bilateral economic agreements containing investment chapters, 3) Other related investment agreements involving more than 2 countries. Salacuse, J. W. (2010). The emerging global regime for investment. Harv. Int'l LJ, 51 , $427-428$.

${ }^{7}$ Ibid, p. 444

${ }^{8}$ Voss, J. O. (2010). The impact of investment treaties on contracts between host states and foreign investors. Leiden: Brill. p. 81

${ }^{9}$ Latif, B. (2009). Kedudukan Bilateral Investment Treaties (Bits) Dalam Perkembangan Hukum Investasi Di Indonesia. Universitas Airlangga.

${ }^{10}$ Vandevelde, K. J. (2005). A brief history of international investment agreements. UC Davis J. Int'l L. \& Pol'y, $12,157.157$.

${ }^{11}$ Sornarajah, M. (2021). The international law on foreign investment. Cambridge university press. Graving, R. J. (1986). International Business Transactions-A Problem-Oriented Coursebook. p. 905.

${ }^{12}$ Hardori, G. (2021). Implementasi Bilateral Investment Treaty Antara Indonesia Dan Korea Selatan Periode 2014-2018. Moestopo Journal of International Relations, 1(2), 115-126.

${ }^{13}$ Hidayati, E. H., Suhaidi, S., Siregar, M., \& Leviza, J. (2017). Akibat Penghentian Bilateral Investment Treaty (Bit) Indonesia-Belanda Yang Dilakukan Secara Sepihak Oleh Indonesia. USU Law Journal, 5(2).
} 
losses suffered by corporations due to war, armed conflict, revolution, state emergency, riots, or rebellion. Usually this protection is in the form of compensation or reparation;

3) Protection from expropriation or nationalization and requiring the provision of compensation;

4) Dispute settlement mechanism, aligning the level of investors with the state or known as Investor State Dispute Settlement / ISDS.

The protection itself is an attraction for investors to invest in the host state so that with the protection, promotion will be achieved. In addition, each investment agreement title indicates that the purpose of the agreement is not only promotion but also protection.

A report issued by the United Nations Conference on Trade and Development (UNCTAD) in 2018 indicates a crisis of legitimacy in the international investment regime: Countries, especially developing countries and the least-developed countries, are increasingly critical of the global economic order. Foreign investment agreements, especially BITs that are relied upon (host state) in triggering foreign direct investment's flows since the 1990s, only confirmed 18 instruments in 2017; recorded at least since 1983. This is inversely proportional to the trend of discontinuation which is even more lively. In fact, in order to strengthen state control or control over their natural wealth, countries have begun to recreate restrictions and regulations that actually suspend investment; to the extent that the investment agreement is deemed to be against or does not accommodate national interests.

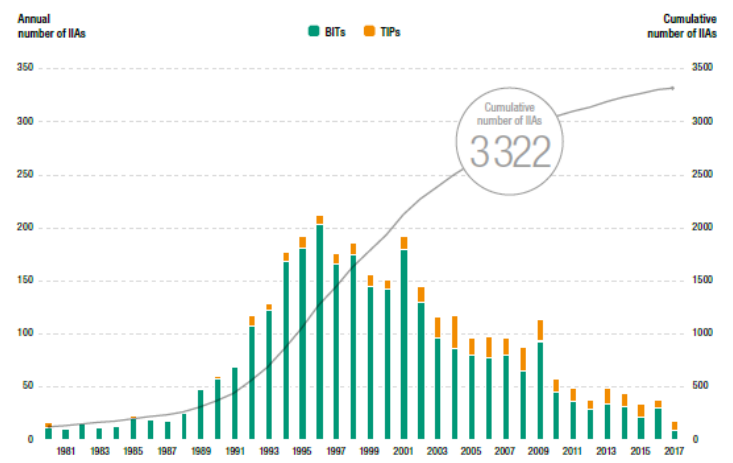

Figure 1. Trends in International Investment Agreements 1980-2017, source: United Nations Conference on Trade and Development (UNCTAD), "World Investment Report 2018: Investment and New Industrial Policies", 2020.

Based on data from the United Nations Trade and Development (UNCTAD), until 2020 there are 2902 BITs in the world and as many as 2342 BITs are still valid. ${ }^{1}$ Meanwhile, the BITs in which Indonesia is one of the participants are 60 BITs, 26 BITs are still valid, 16 BITs have only been signed and 30 BITs have expired or been terminated. ${ }^{2}$

One of the components in the BIT is the Investor-State Dispute Settlement (ISDS), which is a clause in the BIT that discusses dispute settlement between the State and Investors. This deviates from the dispute resolution mechanism in international law in general where international disputes are resolved between states. ISDS strips away the sovereign nature of a state in which the state can be sued directly by non-state legal subjects in the context of international relations.

Indonesia reviewed its BIT because of the many lawsuits brought against Indonesia, including the Churchil Mining case. Indonesia reviewed 63 BITs signed by Indonesia and partner countries. Some points that need to be revised are the following clauses:
1) Opening
2) Definition
3) Fair and Equitable Treatment
4) Most Favorite Nation
5) National Treatment
6) Expropriation and Nationalization
7) Investor-State Dispute Resolution (ISDS)

One of the objectives of establishing the state government of the Republic of Indonesia is to create welfare for its people based on Pancasila and the 1945 Constitution of the Republic of Indonesia. Article 33 paragraph 3 of the 1945 Constitution states that "Earth, water and natural resources contained therein are controlled by the State and used for the greatest prosperity of the people". This shows that Indonesia has sovereignty in the natural

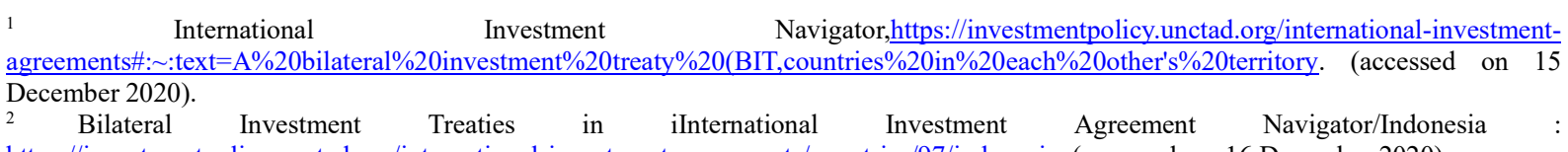
https://investmentpolicy.unctad.org/international-investment-agreements/countries/97/indonesia, (accessed on 16 December 2020). 
resource management sector, meaning that Indonesia has full power to manage all the potential of Indonesia's natural resources and use it to realize the welfare and prosperity of the people. ${ }^{1}$

The concern felt from the implementation of the BIT is the BIT dispute resolution mechanism, namely the ISDS is easily accessible by investors to sue the State. The existence of an ISDS clause in the BIT made by Indonesia because Indonesia has ratified the Convention on the Settlement of Investment Dispute Between States and Nationals of Other States (ICSID Convention), which is stated in the Law of the Republic of Indonesia No. 5 of 1968. This is confirmed in Article 1 of this Law which states that Indonesia has agreed to the convention. In addition, one of the pressing concerns regarding the implementation of this BIT is that the value of the claims being sued by investors is sometimes too large to burden the state's finances. This of course can hinder the goals of the people's welfare and prosperity. Based on article 18 letter h of Law no. 24 of 2000, a sovereign state can take action to stop it for the sake of the continuity of its national interest. In line with this, the mandate of Law no. 25 of 2007 which is to create an investment cycle that is conducive, optimal and still prioritizes the national interest. This is also in accordance with the mandate of Article 33 of the 1945 Constitution of the Republic of Indonesia, so that a BIT Indonesia model is needed which is made by the Indonesian government and related parties, containing clauses that still reflect national interests.

\section{B. Methods of Research}

This research is a normative ${ }^{2}$ research with statutory and case approach. The research material was analyzed using descriptive methods and providing prescriptive arguments. ${ }^{3}$

\section{Results and Discussion}

\section{Aspects of Public Welfare}

Investment is felt to be very necessary for countries as victims of war in the post-World War II period where the condition of the country really needs help from other parties or countries to improve various conditions including infrastructure in their country. Investments may be needed by countries in the period of independence because at any time a country may need capital assistance from a stronger country. Likewise Indonesia, Indonesia made investment agreements with other countries.

BIT is an investment agreement made to ensure investors feel safe when investing in a host country. The sense of security in this case is security from regulations made by or measures taken by the host state government that can harm investors. This also applies to the Indonesian government as the host state.

Regulations and measures taken by the Indonesian government should not harm investors so as not to violate the investment agreements that have been made. After some time Indonesia made investment agreements with other countries, Indonesia received several lawsuits from investors who invested their capital in Indonesia. This lawsuit is directly from the investor, not from the government of the investor's country of origin. The existence of equality between investors and the state was deemed very inappropriate for the Indonesian government from the point of view of International Law at that time, and the Indonesian government felt that the government was always easily sued. This is what caused the Indonesian government in 2014 to review the BIT that had been made by Indonesia. As a result of the review, some BITs were discontinued and some were still valid and others were only signed and not valid.

The reform of the clauses in the BIT is also one of the results of the review because it is felt that there is no balance of rights and obligations between the host state and investors in the BIT. The host state government regulations and measures that cause investors to sue the host state, one of which is the existence of a public policy clause that is applied in the host state, including the public welfare because investors feel disadvantaged by the public policy.

Welfare can be interpreted as various actions taken by humans to achieve a better level of community life. Law of the Republic of Indonesia No. 11 of 2009 article 1 paragraph 1, states that the purpose of welfare is: Social Welfare is a condition of being fulfilled the material, spiritual, and social needs of citizens in order to live properly and be able to develop themselves, so that they can carry out their social functions.

Welfare can also be interpreted as an overall effort that is organized and has the aim of improving people's living standards based on their social context. It also includes elements of policies and services in a broad sense related to various aspects of people's lives, such as income, social security, health, housing, education, recreation, cultural traditions and others. ${ }^{4}$

The conclusion from the notion of welfare is that welfare includes various efforts developed to improve the standard of human life, both in the physical, mental, emotional, socio-economic or spiritual life fields. The

\footnotetext{
${ }^{1}$ Saleng, A. (2013). Kapita Selekta Hukum Sumber Daya Alam. Makassar: Membumi Publishing. p5.

${ }^{2}$ Soekanto, S., \& Mamudji, S. (2014). Penelitian Hukum Normatif Suatu Tinjauan Singkat. Jakarta: Rajawali Pers. p. 13

${ }^{3}$ Irwansyah. (2020). Penelitian hukum : pilihan metode \& praktik penulisan artikel. Yogyakarta: Mirra Buana Media

${ }^{4}$ Santo, E. T., Singkoh, F., \& Kairupan, J. (2018). Peran Pemerintah Desa Dalam Pengembangan Potensi Desa Untuk Meningkatkan Kesejahteraan Masyarakat Di Masani Kecamatan Poso Pesisir Barat Kabupaten Poso. Jurnal Eksekutif, 1(1).
} 
welfare aspect is one of the indicators in terms of the national interest, in addition to the certainty of security, freedom, and justice. ${ }^{1}$ Explanation of the Law of the Republic of Indonesia No. 25 of 2007 also states that one of the goals of establishing a state government is the general welfare. In this regard, the welfare of the community is placed as the goal of implementing investment. The welfare of the community in an area can be measured by

\begin{tabular}{|c|c|c|c|c|c|c|}
\hline No. & Short title & Parties & Status & $\begin{array}{l}\begin{array}{l}\text { Date of } \\
\text { signature }\end{array} \\
\end{array}$ & $\begin{array}{l}\text { Date of entry } \\
\text { into force }\end{array}$ & $\begin{array}{l}\text { Date } \\
\text { termination }\end{array}$ \\
\hline 1. & Indonesia - Singapore BIT (2018) & Indonesia; Singapore; & In force & $11-10-2018$ & 09-03-2021 & \\
\hline 2. & Indonesia - Serbia BIT (2011) & Indonesia; Serbia; & Signed & 06-09-2011 & & \\
\hline 3. & Indonesia - Libya BIT (2009) & Indonesia; Libya; & Signed & 04-04-2009 & & \\
\hline 4. & Guyana - Indonesia BIT (2008) & Guyana; Indonesia; & Signed & $30-01-2008$ & & \\
\hline 5. & $\begin{array}{l}\text { Indonesia - Russian Federation BIT } \\
(2007)\end{array}$ & Indonesia; Russian Federation; & In force & 06-09-2007 & $15-10-2009$ & \\
\hline 6. & Denmark - Indonesia BIT (2007) & Denmark; Indonesia; & In force & $22-01-2007$ & $15-10-2009$ & \\
\hline 7. & Finland - Indonesia BIT (2006) & Finland; Indonesia; & In force & $12-09-2006$ & $02-08-2008$ & \\
\hline 8. & $\begin{array}{l}\text { Indonesia - Iran, Islamic Republic of } \\
\text { BIT (2005) }\end{array}$ & $\begin{array}{l}\text { Indonesia; Iran, Islamic Republic } \\
\text { of; }\end{array}$ & In force & $22-06-2005$ & 28-03-2009 & \\
\hline 9. & Indonesia - Singapore BIT (2005) & Indonesia; Singapore; & Terminated & $16-02-2005$ & $21-06-2006$ & $20-06-2016$ \\
\hline 10. & Indonesia - Tajikistan BIT (2003) & Indonesia; Tajikistan; & Signed & $28-10-2003$ & & \\
\hline 11. & Indonesia - Saudi Arabia BIT (2003) & Indonesia; Saudi Arabia; & In force & $15-09-2003$ & $05-07-2004$ & \\
\hline 12. & Bulgaria - Indonesia BIT (2003) & Bulgaria; Indonesia; & Terminated & 13-09-2003 & $23-01-2005$ & $25-01-2015$ \\
\hline 13. & Germany - Indonesia BIT (2003) & Germany; Indonesia; & Terminated & $14-05-2003$ & $02-06-2007$ & 01-06-2017 \\
\hline 14. & Croatia - Indonesia BIT (2002) & Croatia; Indonesia; & Signed & $10-09-2002$ & & \\
\hline 15. & Indonesia - Philippines BIT (2001) & Indonesia; Philippines; & Signed & $12-11-2001$ & & \\
\hline 16. & $\begin{array}{l}\text { Indonesia - Venezuela, Bolivarian } \\
\text { Republic of BIT (2000) }\end{array}$ & $\begin{array}{l}\text { Indonesia; Venezuela, Bolivarian } \\
\text { Republic of; }\end{array}$ & In force & $18-12-2000$ & 23-03-2003 & \\
\hline 17. & Indonesia - Qatar BIT (2000) & Indonesia; Qatar; & In force & $18-04-2000$ & $17-02-2018$ & \\
\hline 18. & Algeria - Indonesia BIT (2000) & Algeria; Indonesia; & Signed & $21-03-2000$ & & \\
\hline 19. & $\begin{array}{l}\text { Indonesia - Korea, Dem. People's Rep. } \\
\text { of BIT }(2000)\end{array}$ & $\begin{array}{l}\text { Indonesia; Korea, Dem. People's } \\
\text { Rep. of; }\end{array}$ & Signed & $21-02-2000$ & & \\
\hline 20. & Chile - Indonesia BIT (1999) & Chile; Indonesia; & Signed & 07-04-1999 & & \\
\hline 21. & Indonesia - Mozambique BIT (1999) & Indonesia; Mozambique; & In force & 26-03-1999 & $25-07-2000$ & \\
\hline 22. & Cambodia - Indonesia BIT (1999) & Cambodia; Indonesia; & Terminated & 16-03-1999 & & $07-01-2016$ \\
\hline 23. & Indonesia - Jamaica BIT (1999) & Indonesia; Jamaica; & Signed & 10-02-1999 & & \\
\hline 24. & Indonesia - Zimbabwe BIT (1999) & Indonesia; Zimbabwe; & Signed & $10-02-1999$ & & \\
\hline 25. & India - Indonesia BIT (1999) & India; Indonesia; & Terminated & 10-02-1999 & $22-01-2004$ & $07-04-2016$ \\
\hline 26. & Czech Republic - Indonesia BIT (1998) & Czechia; Indonesia; & In force & 17-09-1998 & 21-06-1999 & \\
\hline 27. & Indonesia - Yemen BIT (1998) & Indonesia; Yemen; & Signed & $20-02-1998$ & & \\
\hline 28. & Indonesia - Thailand BIT (1998) & Indonesia; Thailand; & In force & $17-02-1998$ & 05-11-1998 & \\
\hline 29. & Indonesia - Sudan BIT (1998) & Indonesia; Sudan; & Signed & $10-02-1998$ & & \\
\hline 30. & Bangladesh - Indonesia BIT (1998) & Bangladesh; Indonesia; & In force & 09-02-1998 & 22-04-1999 & \\
\hline 31. & Cuba - Indonesia BIT (1997) & Cuba; Indonesia; & In force & 19-09-1997 & 29-09-1999 & \\
\hline 32. & $\begin{array}{l}\text { Indonesia - Syrian Arab Republic BIT } \\
\text { (1997) }\end{array}$ & Indonesia; Syrian Arab Republic; & In force & 27-06-1997 & $20-02-2000$ & \\
\hline 33. & Indonesia - Romania BIT (1997) & Indonesia; Romania; & Terminated & $27-06-1997$ & 21-08-1999 & $07-01-2016$ \\
\hline 34. & Indonesia - Morocco BIT (1997) & Indonesia; Morocco; & In force & 14-03-1997 & $21-03-2002$ & \\
\hline 35. & Indonesia - Mauritius BIT (1997) & Indonesia; Mauritius; & In force & 05-03-1997 & $28-03-2000$ & \\
\hline 36. & Indonesia - Mongolia BIT (1997) & Indonesia; Mongolia; & In force & 04-03-1997 & $13-04-1999$ & \\
\hline 37. & Indonesia - Turkey BIT (1997) & Indonesia; Turkey; & Terminated & $25-02-1997$ & 28-09-1998 & 07-01-2016 \\
\hline 38. & Indonesia - Jordan BIT (1996) & Indonesia; Jordan; & In force & $12-11-1996$ & 09-02-1999 & \\
\hline 39. & Indonesia - Uzbekistan BIT (1996) & Indonesia; Uzbekistan; & In force & 27-08-1996 & 27-04-1997 & \\
\hline 40. & Indonesia - Sri Lanka BIT (1996) & Indonesia; Sri Lanka; & In force & $10-06-1996$ & 21-07-1997 & \\
\hline 41. & Indonesia - Ukraine BIT (1996) & Indonesia; Ukraine; & In force & $11-04-1996$ & $22-06-1997$ & \\
\hline 42. & Finland - Indonesia BIT (1996) & Finland; Indonesia; & Terminated & 13-03-1996 & 07-06-1997 & $02-08-2008$ \\
\hline 43. & Indonesia - Pakistan BIT (1996) & Indonesia; Pakistan; & Terminated & 08-03-1996 & 03-12-1996 & $02-12-2016$ \\
\hline 44. & Argentina - Indonesia BIT (1995) & Argentina; Indonesia; & Terminated & $07-11-1995$ & 01-03-2001 & 19-10-2016 \\
\hline 45. & Indonesia - Suriname BIT (1995) & Indonesia; Suriname; & Signed & $28-10-1995$ & & \\
\hline 46. & Indonesia - Kyrgyzstan BIT (1995) & Indonesia; Kyrgyzstan; & Terminated & 19-07-1995 & $23-04-1997$ & $18-02-2018$ \\
\hline 47. & Indonesia - Spain BIT (1995) & Indonesia; Spain; & Terminated & $30-05-1995$ & 18-12-1996 & $18-12-2016$ \\
\hline 48. & China - Indonesia BIT (1994) & China; Indonesia; & Terminated & 18-11-1994 & 01-04-1995 & 31-03-2015 \\
\hline 49. & $\begin{array}{l}\text { Indonesia - Lao People's Democratic } \\
\text { Republic BIT (1994) }\end{array}$ & $\begin{array}{lcc}\text { Indonesia; } \quad \text { Lao } & \text { People's } \\
\text { Democratic Republic; } & \\
\end{array}$ & Terminated & $18-10-1994$ & $14-10-1995$ & $13-10-2015$ \\
\hline 50. & Indonesia - Slovakia BIT (1994) & Indonesia; Slovakia; & Terminated & $12-07-1994$ & 01-03-1995 & $28-02-2015$ \\
\hline 51. & Indonesia - Turkmenistan BIT (1994) & Indonesia; Turkmenistan; & Signed & 02-06-1994 & & \\
\hline 52. & Indonesia - Netherlands BIT (1994) & Indonesia; Netherlands; & Terminated & 06-04-1994 & $01-07-1995$ & $30-06-2015$ \\
\hline 53. & Indonesia - Malaysia BIT (1994) & Indonesia; Malaysia; & Terminated & 22-01-1994 & $27-10-1999$ & $20-06-2015$ \\
\hline 54. & Egypt - Indonesia BIT (1994) & Egypt; Indonesia; & Terminated & $19-01-1994$ & $29-11-1994$ & $30-11-2014$ \\
\hline 55. & Australia - Indonesia BIT (1992) & Australia; Indonesia; & Terminated & $17-11-1992$ & $29-07-1993$ & 06-08-2020 \\
\hline 56. & Indonesia - Poland BIT (1992) & Indonesia; Poland; & In force & $06-10-1992$ & 01-07-1993 & \\
\hline 57. & Indonesia - Sweden BIT (1992) & Indonesia; Sweden; & In force & $17-09-1992$ & $18-02-1993$ & \\
\hline 58. & Hungary - Indonesia BIT (1992) & Hungary; Indonesia; & Terminated & $20-05-1992$ & 13-02-1996 & $12-02-2016$ \\
\hline 59. & Indonesia - Tunisia BIT (1992) & Indonesia; Tunisia; & In force & $13-05-1992$ & 12-09-1992 & \\
\hline 60. & Indonesia - Norway BIT (1991) & Indonesia; Norway; & Terminated & 26-11-1991 & 01-10-1994 & 30-09-2004 \\
\hline 61. & Indonesia - Viet Nam BIT (1991) & Indonesia; Viet Nam; & Terminated & $25-10-1991$ & 03-04-1994 & 07-01-2016 \\
\hline 62. & Indonesia - Italy BIT (1991) & Indonesia; Italy; & Terminated & $25-04-1991$ & $25-06-1995$ & $23-06-2015$ \\
\hline
\end{tabular}

${ }^{1}$ Murti, E., Iswati, R., \& Wiyaka, A. (2018). Wirausaha Dalam Meningkatkan Kesejahteraan Ekonomi Masyarakat Di Desa Baderan. Jurnal Sosial: Jurnal Penelitian Ilmu-Ilmu Sosial, 19(2), 130-135. 


\begin{tabular}{|c|c|c|c|c|c|c|}
\hline No. & Short title & Parties & Status & $\begin{array}{ll}\begin{array}{l}\text { Date of } \\
\text { signature }\end{array} & \text { of } \\
\end{array}$ & $\begin{array}{l}\text { Date of entry } \\
\text { into force }\end{array}$ & $\begin{array}{ll}\text { Date } & \text { of } \\
\text { termination }\end{array}$ \\
\hline 63. & $\begin{array}{l}\text { Indonesia - Korea, Republic of BIT } \\
\text { (1991) }\end{array}$ & Indonesia; Korea, Republic of; & In force & $16-02-1991$ & 10-03-1994 & \\
\hline 64. & Indonesia - Singapore BIT (1990) & Indonesia; Singapore; & Terminated & $28-08-1990$ & $28-08-1990$ & $20-06-2006$ \\
\hline 65. & $\begin{array}{l}\begin{array}{l}\text { Indonesia } \\
(1976)\end{array}\end{array}$ & Indonesia; United Kingdom; & In force & 27-04-1976 & 24-03-1977 & \\
\hline 66. & Indonesia - Switzerland BIT (1974) & Indonesia; Switzerland; & Terminated & 06-06-1974 & 09-04-1976 & $08-04-2016$ \\
\hline 67. & France - Indonesia BIT (1973) & France; Indonesia; & Terminated & 14-06-1973 & $29-04-1975$ & $29-04-2015$ \\
\hline 68. & Belgium - Indonesia BIT (1970) & Belgium; Indonesia; & Terminated & $15-01-1970$ & $17-06-1972$ & $16-06-2002$ \\
\hline 69. & Indonesia - Norway BIT (1969) & Indonesia; Norway; & Terminated & $26-11-1969$ & & $01-10-1994$ \\
\hline 70. & Germany - Indonesia BIT (1968) & Germany; Indonesia; & Terminated & $08-11-1968$ & 19-04-1971 & $02-06-2007$ \\
\hline 71. & Indonesia - Netherlands BIT (1968) & Indonesia; Netherlands; & Terminated & $07-07-1968$ & $17-07-1971$ & $01-07-1995$ \\
\hline 72. & Denmark - Indonesia BIT (1968) & Denmark; Indonesia; & Terminated & $30-01-1968$ & $02-07-1968$ & $15-10-2009$ \\
\hline
\end{tabular}

the level of population, health and nutrition, education, employment, level and pattern of consumption, housing and environment, poverty, and other social factors that serve as references in efforts to improve the quality of life. ${ }^{1}$ Indonesia has made 72 BITs but not all of them are valid. Some BITs are simply signed (but not valid) and some BITs are not continued or terminated. The following are BITs made by Indonesia, both in force, only signed and terminated:

The table shows that there are 72 BITs that have been made by Indonesia with other countries, with information that 26 BITs are still in force, 15 BITs are only signed, and 31 BITs are not continued or terminated.

The termination of a large number of BITs was due to a review carried out during the administration of Susilo Bambang Yudoyono after Indonesia was sued before ICSID and had to pay a fairly large amount of the lawsuit.

The BITs currently in force are:

1) Indonesia - Singapore BIT (2018)

2) Indonesia - Russian Federation BIT (2007)

3) Denmark - Indonesia BIT (2007)

4) Finland - Indonesia BIT (2006)

5) Indonesia - Iran, Islamic Republic of BIT (2005)

6) Indonesia - Saudi Arabia BIT (2003)

7) Indonesia - Venezuela, Bolivarian Republic of BIT (2000)

8) Indonesia - Qatar BIT (2000)

9) Indonesia - Mozambique BIT (1999)

10) Czech Republic - Indonesia BIT (1998)

11) Indonesia - Thailand BIT (1998)

12) Bangladesh - Indonesia BIT (1998)

13) Cuba - Indonesia BIT (1997)

14) Indonesia - Syrian Arab Republic BIT (1997)

15) Indonesia - Morocco BIT (1997)

16) Indonesia - Mauritius BIT (1997)

17) Indonesia - Mongolia BIT (1997)

18) Indonesia - Jordan BIT (1996)

19) Indonesia - Uzbekistan BIT (1996)

20) Indonesia - Sri Lanka BIT (1996)

21) Indonesia - Ukraine BIT (1996)

22) Indonesia - Poland BIT (1992)

23) Indonesia - Sweden BIT (1992)

24) Indonesia - Tunisia BIT (1992)

25) ndonesia - Korea, Republic of BIT (1991)

26) Indonesia - United Kingdom BIT (1976)

If it is linked between the meaning and what is included in the welfare of the community or a sentence that clearly mentions the welfare of the community, it will be difficult to find in the Indonesian BIT which is still valid. Public welfare is included in actions or if regulations are made, it has the potential to cause harm to investors so that investors can easily sue the host state before arbitration. There is one BIT that mentions this public policy, namely the latest BIT between Indonesia and Singapore, signed on 11-10-2018 and coming into

${ }^{1}$ Gunawan Nachrawi, S. H. (2021). Bumn Sebagai Usaha Pemerintah Menuju Kesejahteraan Rakyat: Tinjauan Filosofis, Sosiologis, Politis Dan Yuridis. Bandung: CV Cendekia Press. 
force on 09-03-2021.

This Indonesia-Singapore BIT is a BIT made by Indonesia after the review process for the Indonesian BITBIT which is still valid. This Indonesia-Singapore BIT includes sentences that reflect the content of public welfare, namely Article 11 "Right to Regulate", including "protection of public health, social services, education, safety, environment and public morals, social or consumer protection.. ${ }^{1}$

Article 11 paragraph (1) mentions the right to regulate each party (home state and host state) in order to achieve legitimate policy objectives. The next paragraph in the same article states that with the right to regulate this, including through changes to the laws and regulations of each party, if there is a fact that this has a negative impact on investment or affects investment expectations, including profit expectations, then the implementation of this regulatory right shall not constitute a breach of the obligations under this Agreement.

Article 11 is an example of an exception to public policy including public welfare which is usually avoided because it can violate obligations in the BIT so that investors can easily sue the host state on the grounds that these public welfare measures do not protect or actually harm investors when investing in the host state area. Public policy exemptions in investment treaties allow governments to lawfully take actions directed at specific regulatory goals, industries, or sectors of the economy that are inherently inconsistent with treaty obligations. ${ }^{2}$

The government can inject this public welfare in the BIT it makes through ${ }^{3}$ :

1) The definition of investment, it can be determined that the investment must contain the following elements:

a) Contribution of money/assets

b) Risk

c) Duration

d) Contribution to the economy of the host state

2) Some exceptions, which are certain measures (measures) that are not considered as expropriation, include:

a) Approach to the Right to regulate clause for the purpose of the public interest, which is the latest approach in investment agreements;

b) General exceptions in article XX GATT

c) Compulsory license for specific purpose.

The "Right to Regulate" clause is also applied in other investment agreements, namely the IndonesiaAustralia CEPA Investment Chapter (2019) and the Indonesia-European CEPA Investment Chapter.

\section{Aspects of Public Protection}

The aspect of public protection can be said to be one of the public policies. As discussed earlier, one of the reasons investors sued the host state is because there are public policies taken by the host state, which are considered to be detrimental to investors. As for the aspect of community protection here, it can be interpreted as social protection which is an integral aspect in the development process as well as poverty alleviation and reduction of inequality in a country. ${ }^{4}$ The ideals of the Indonesian nation for a social protection system or protection of the community have been mandated in the 1945 Constitution. The preamble to the 1945 Constitution mandates that the government must protect the entire nation and the entire homeland, promote public welfare, and educate the nation's life. ${ }^{5}$ The definition of social protection according to Bappenas is all initiatives carried out by the government, the private sector, or the community to realize the transfer of income or consumption to the poor, protect vulnerable groups from livelihood risks, and improve the social status of marginalized groups. ${ }^{6}$

BIT which contains the content of community protection is needed to provide a balance between rights and obligations between investors and the national interest. If you look at all Indonesian BITs with other countries that are still valid, only 1 BIT contains public protection, namely the latest BIT between Indonesia and Singapore, signed on 11-10-2018 and coming into force on 09-03-2021. The latest Indonesia-Singapore BIT contains a clause that mentions the protection of the community, namely in article 11 concerning the Right to Regulate. This article states that the parties, in this case the Government of Indonesia and the Government of Singapore

\footnotetext{
${ }^{1}$ Pasal 11 BIT Indonesia-Singapura, https://investmentpolicy.unctad.org/international-investment-agreements/treaties/bilateral-investmenttreaties/3828/indonesia---singapore-bit-2018- diakses tanggal 27 November 2020.

${ }^{2}$ Henckels, C. (2018). Should investment treaties contain public policy exceptions. BCL Rev., 59, p. 2826.

${ }^{3}$ Results of an interview with Mr. Syahda Guruh Step Samudera, Director of Huhum and Economic Agreements, Ministry of Foreign Affairs of the Republic of Indonesia, via zoom on June 9, 2021 at 15.40 WITA.

4 Direktorat Perlindungan dan Kesejahteraan Masyarakat, Kementerian Perancanaan Pembangunan Nasional/Badan Perencanaan Pembangunan Nasional (2014). Perlindungan Sosial di Indonesia, Tantangan dan Arahan ke Depan. Jakarta: Bappenas, p. 2 , https://www.bappenas.go.id/files/5114/2889/4558/Perlindungan_Sosial_di_IndonesiaTantangan_dan_Arah_ke_Depan.pdf, Accessed on 7 June 2021.

${ }^{5}$ Ibid.

${ }^{6}$ Ibid.
} 
affirm their right to regulate within their territory, namely the territory of Indonesia and the territory of Singapore, in order to achieve legitimate policy objectives, such as the protection of public health, social services, education, safety. environmental and public morals, social or consumer protection, privacy and data protection and the promotion and protection of cultural diversity. This shows that the latest Indonesia-Singapore BIT has included aspects of protecting the community as an effort to balance the rights and obligations of investors and the host state.

\section{Conclusion}

The current Indonesian investment agreement does not fully contain the national interest because it is based on social welfare based on Law no. 11 of 2009 has not been achieved by looking at the fact that there are still many people around the Freeport mining area who are still under poverty and housing and health conditions are very minimal compared to luxury buildings around the mine. In addition, the customary tribes around the investment (mining) location have their ulayat rights taken away and do not get protection. Based on economic theory, especially the middle way theory, investment agreements should not only provide benefits to investors but must also provide benefits to the recipient country of capital in this case the national interest.

\section{References}

Bjorklund, A. (2005). Foreword: Symposium: Romancing the Foreign Investor Bit by Bit. UC Davis Journal of International Law and Policy, 12(1).

Direktorat Perlindungan dan Kesejahteraan Masyarakat, Kementerian Perancanaan Pembangunan Nasional/Badan Perencanaan Pembangunan Nasional (2014). Perlindungan Sosial di Indonesia, Tantangan dan Arahan ke Depan. Jakarta: Bappenas.

Graving, R. J. (1986). International Business Transactions-A Problem-Oriented Coursebook.

Gunawan Nachrawi, S. H. (2021). Bumn Sebagai Usaha Pemerintah Menuju Kesejahteraan Rakyat: Tinjauan Filosofis, Sosiologis, Politis Dan Yuridis. Bandung: CV Cendekia Press.

Hardori, G. (2021). Implementasi Bilateral Investment Treaty Antara Indonesia Dan Korea Selatan Periode 2014-2018. Moestopo Journal of International Relations, 1(2), 115-126.

Hata, (2021). Perdagangan internasional dalam sistem GATT dan WTO; Aspek-aspek hukum dan non hukum. Bandung: Refika Aditama.

Henckels, C. (2018). Should investment treaties contain public policy exceptions. BCL Rev., 59, p. 2826.

Hidayati, E. H., Suhaidi, S., Siregar, M., \& Leviza, J. (2017). Akibat Penghentian Bilateral Investment Treaty (Bit) Indonesia-Belanda Yang Dilakukan Secara Sepihak Oleh Indonesia. USU Law Journal, 5(2).

Irwansyah. (2020). Penelitian hukum : pilihan metode \& praktik penulisan artikel. Yogyakarta: Mirra Buana Media

Latif, Birkah. (2009). Kedudukan Bilateral Investment Treaties (Bits) Dalam Perkembangan Hukum Investasi Di Indonesia. Universitas Airlangga.

Lobubun, M., Saleng, A., \& Suriyaman M Pide, A. (2018). The Connection of Authority between Central Government and Regional Government in Managing Mining and Forestry in Papua. JL Pol'y \& Globalization, 69, 170.

M Sornarajah, M. (2021). The international law on foreign investment. New York: Cambridge university press.

Murti, E., Iswati, R., \& Wiyaka, A. (2018). Wirausaha Dalam Meningkatkan Kesejahteraan Ekonomi Masyarakat Di Desa Baderan. Jurnal Sosial: Jurnal Penelitian Ilmu-Ilmu Sosial, 19(2), 130-135.

QC, S. P. S. (2020). International investment law: reconciling policy and principle. New York: Bloomsbury Publishing.

Ricardo, D. (1891). Principles of political economy and taxation. G. Bell and sons.

Salacuse, J. W. (2010). The emerging global regime for investment. Harv. Int'l LJ, 51, 427- 428.

Saleng, Abrar. (2013). Kapita Selekta Hukum Sumber Daya Alam. Makassar: Membumi Publishing.

Santo, E. T., Singkoh, F., \& Kairupan, J. (2018). Peran Pemerintah Desa Dalam Pengembangan Potensi Desa Untuk Meningkatkan Kesejahteraan Masyarakat Di Masani Kecamatan Poso Pesisir Barat Kabupaten Poso. Jurnal Eksekutif, 1(1).

Soekanto, S., \& Mamudji, S. (2014). Penelitian Hukum Normatif Suatu Tinjauan Singkat. Jakarta: Rajawali Pers. Sornarajah, M. (2021). The international law on foreign investment. Cambridge university press.

Sumardi, J. (2012). Hukum perusahaan transnasional \& franchise. Makassar: Arus Timur.

Vandevelde, K. J. (2005). A brief history of international investment agreements. UC Davis J. Int'l L. \& Pol'y, 12, 157.

Voss, J. O. (2010). The impact of investment treaties on contracts between host states and foreign investors. Leiden: Brill. 